\title{
Rations for polar travel
}

By H. E. Lewis and J. P. Masterton, National Institute for Medical Research, Holly Hill, London, N.W.3

In this paper we shall discuss recent work on sledging rations undertaken in the Division of Human Physiology of the Medical Research Council.

In the polar regions, the terrain may be crossed on foot, by sledge, or by tracked vehicles ('weasels' or 'snow-cats'). Journeys are usually associated with very hard work in an extremely cold environment, man-packing and man-hauling requiring the greatest consistent outputs of energy. High rates of work are required in dogsledging over hummocked snow or if the dog teams are not well trained. Even with mechanical vehicles hard work is often necessary, because the mechanical aids need complex maintenance involving manhandling of fuel, digging vehicles out of snow drifts and rescuing them from crevasses. This was our experience on the British North Greenland Expedition, in which one of the physiological problems was to compute the energy expenditure of polar travellers.

Before this particular programme was formulated we were struck by the fact that our husky dogs voraciously ate human faeces, sometimes in preference to dog pemmican (Masterton, Lewis \& Widdowson, 1955). As we were eating large quantities of fat we thought it possible that undigested fat might appear in the faeces and attract the dogs. However, when the faeces were analysed no excessive amounts of fat were found, and in balance studies it was found that the large amounts of fat and protein eaten by the expedition members were completely utilized. The mean daily intake of men sledging was about 4800 Cal., and an assessment of energy expenditure showed that it closely balanced the intake (Masterton, Lewis \& Widdowson, 1957).

This rate of expenditure was significant because we knew that the sledging ration which we carried, typical of postwar British sledging rations, yielded only 4200 Cal. daily, leaving a deficit of $600 \mathrm{Cal}$. The greater intake of $4800 \mathrm{Cal}$. was possible because unlimited food was offered during the whole of the sledging trips when the investigations were carried out.

From our own experience we knew that men lost weight and became very hungry when they were obliged to keep to the standard ration. Similar observations had also been reported on other expeditions and are confirmed by the findings of Johnson $\&$ Kark (1947) who showed that the voluntary food intake of servicemen in an Arctic environment is as high as $4500-5000 \mathrm{Cal}$./day.

A modern polar expedition has two distinct aspects: (I) the struggle of man against nature and (2) the scientific achievement which, in the long run, is the acid test of the venture. The latter aspect was well expressed by Apsley Cherry-Garrard (1948) who was a member of Scott's last expedition-'. . . whilst we knew we had suffered, and risked better than anyone else, we also knew that science takes no account of such things; that a man is no better for having made the worst journey in the world; 
and that whether he returns alive or drops by the way will all be the same a hundred years hence if his records and specimens come safely to hand. . . '

Men with an adequate calorie intake are better able to carry out scientific work in a difficult environment. We felt that our findings warranted a review of the existing ration scale.

Early in the expedition we became critical of the manner in which our rations were packed and resolved to investigate the possibilities of improvement because we were aware of many advances in food and packaging technology since World War II.

On our return, these ideas were communicated to the Climatic Physiology Committee of the Medical Research Council and we were encouraged to devise a ration not only packed in the most modern way but also yielding the extra calories we had found necessary. We were fortunate in not having to plan for an immediate expedition, for in such an event there is usually not enough time to experiment. For this reason in the past the same rations had been taken time after time to avoid the risk of an untried innovation.

The criteria for a satisfactory sledging ration are: (1) high calorie yield, (2) low weight, (3) small bulk, and (4) strong but low-weight packaging. In addition, there should be palatibility and variety; the rations should be suitable for eating raw in an emergency; the packing should permit easy sharing among a party and should be easy to unwrap; the gross weight of a $20 \mathrm{man} /$ day box of rations should not exceed $50 \mathrm{lb}$.

We approached the Ministry of Agriculture, Fisheries and Food, and the development section of the Metal Box Company. They were more than willing to collaborate with us. The Ministry had been developing improved techniques in dehydration of foods. Among their products is a dehydrated meat bar consisting of approximately $60 \%$ fat and $40 \%$ dehydrated minced beef. This meat may be eaten as it is or may be easily reconstituted into a palatable mince stew. In the past the traditional staple

Table I. One man/day sledging ration used on the British North Greenland Expedition $195^{2-4}$

$\begin{array}{lcc} & \begin{array}{c}\text { Weight } \\ (\text { oz. }\end{array} & \begin{array}{c}\text { Calories } \\ \text { (Cal.) }\end{array} \\ \text { Butter } & 5 \cdot 6 & \text { I26I } \\ \text { Pemmican } & 5 \cdot 6 & 890 \\ \text { Biscuits } & 4 \cdot 3 & 555 \\ \text { Chocolate } & 2 \cdot 4 & 392 \\ \text { Sugar } & 3 \cdot 0 & 339 \\ \text { Rolled oats } & 2 \cdot 3 & 264 \\ \text { Dried milk } & 1 \cdot 6 & 238 \\ \text { Potato powder } & 1 \cdot 6 & 174 \\ \text { Cocoa } & 0 \cdot 4 & 51 \\ & 26.8 & 4164\end{array}$

in the sledging diet has been pemmican, a generic name for a homogenized mixture of fat and meat (cf. Table I). It is of very high caloric value (I59 Cal./oz.). The taste has to be acquired, so as a first step in modifying the sledging ration we decided to substitute the meat bar, which is of similar caloric value. 
The most economical method of increasing the caloric yield in terms of weight would have been to add more fat to the ration. However, only a little more fat could be tolerated and the bulk of the increase had to be distributed between carbohydrate and protein, which led to a final daily food weight of 32 oz. net (Table 2).

We had decided to dispense with the bulk containers, such as one large tin holding 7 lb. of butter, and to adopt packaging units of 2 man-days using foil, Polythene and other flexible wraps for individual items. The daily ration for two men was contained in one large Polythene envelope. We had thus increased the weight of the food in order to increase the calories, but saved weight by substituting light plastics for tins. By adopting disposable unit packs the dead weight of empty bulk tins was avoided. Thus, by the end of the journey, the total weight carried would be of the same order as in the old rations.

As has been mentioned above, the new prototype ration includes meat bar instead of pemmican. Increases were made in chocolate, milk powder, rolled oats, and cocoa, now in the form of drinking chocolate. Sweets, cheese and dehydrated soup, listed in order of total calorie yield, were introduced to give extra calories. Sweets provide immediate energy, and, being highly flavoured, are most acceptable on the trail when water is not readily available. It would seem that in practice only pasteurized (processed) cheese can be taken, as natural cheese will not survive a journey through the tropics. Dehydrated soup could be substituted for the potato powder traditionally included in the rations and, in fact, also included by us. A wide variety of thick soup powders are available commercially in attractive foil pouches, but it is important to include only the quick-cooking brands.

Table 2. One man/day Medical Research Council sledging ration: suggested third prototype (not final)

\begin{tabular}{|c|c|c|}
\hline & $\begin{array}{c}\text { Weight } \\
\text { (oz.) }\end{array}$ & $\begin{array}{l}\text { Calories } \\
\text { (Cal.) }\end{array}$ \\
\hline Butter & 5.0 & 1130 \\
\hline Meat bar & $6 \cdot 0$ & 972 \\
\hline Chocolate & $4 \cdot 0$ & 656 \\
\hline Biscuits & $4 \cdot 0$ & $55^{\circ}$ \\
\hline Milk powder & $2 \cdot 0$ & 300 \\
\hline Sugar & $3 \cdot 0$ & 336 \\
\hline Porridge oats & $2 \cdot 0$ & 230 \\
\hline Potato powder & $2 \cdot 0$ & 2.18 \\
\hline Drinking chocolate & $I \cdot 0$ & $128+$ \\
\hline Boiled sweets & $r \cdot 0$ & II 2 \\
\hline Cheese & $x \cdot 0$ & $\begin{array}{l}\text { I20 approx. } \\
\text { (as processed) }\end{array}$ \\
\hline Sultanas & 0.5 & $3^{6}$ \\
\hline \multicolumn{3}{|l|}{ Extras: } \\
\hline Curry powder & 0.2 & - \\
\hline Marmite & 0.1 & - \\
\hline Salt and pepper & 0.1 & - \\
\hline Tea powder & 0.2 & - \\
\hline Coffee powder & Trace & - \\
\hline $\begin{array}{l}\text { (Sufficient for } 2 \mathrm{pt} \text {. } \\
\text { Total (appr }\end{array}$ & $\begin{array}{c}\operatorname{lan} / \text { day) } \\
32 \cdot x\end{array}$ & 4788 \\
\hline
\end{tabular}


The following items, though not yielding calories, were included to increase interest in the fare: curry powder, Marmite, salt and pepper. Finally, tea and coffee were introduced as drinks, both in a soluble form which considerably simplifies preparation.

This sledging ration is based on two previous Medical Research Council prototypes which have been used in the field. We have asked the users of our boxes to complete a full questionnaire and from their answers we will be guided as to further modifications. It is hoped that the M.R.C. rations may become available commercially and that only small changes from time to time will be necessary to keep them up-to-date. This will simplify the victualling problems of expeditions, for the final product will represent the accumulated experience of a large number of polar travellers.

\section{REFERENCES}

Cherry-Garrard, A. (1948). The Worst Fourney in the World. London: Penguin Books. Johnson, R. E. \& Kark, R. M. (1947). Science, ro5, 378.

Masterton, J. P., Lewis, H. E. \& Widdowson, E. M. (1955). Proc. Nutr. Soc. 14, xvi.

Masterton, J. P., Lewis, H. E. \& Widdowson, E. M. (1957). Brit. F. Nutr. xI, 346.

\section{Heat stress and nutrition}

By R. H. Fox, National Institute for Medical Research, Holly Hill, London, N.W.3

The manner and extent of the modifications to man's nutritional needs and status resulting from exposure to the heat stress of tropical living have long been of interest to physiologists.

Early writers were perhaps mainly concerned with the immediate effects of individual items of food. Paulus Aegineta ( 1844 ) commenting on the properties of pot-herbs in the seventh century writes: "The lettuce is manifestly refrigerant and moistening; it is therefore soporific, and, compared with other pot-herbs, nutritious, forming blood of a very good quality.' Others, a little more recently, have made some very shrewd comments. Thus Parkes (I 883), when discussing the diet of troops in India some time before $188_{3}$, gives this advice: 'Our best guide at present for the quantity of food to be taken in the tropics, is to apportion it to the amount of mechanical work done, as in temperate climates. In India, as elsewhere, it must be in balance with exercise.' The reviewer of today has the benefit of an enormous mass of relevant data and yet he wonders whether we can really improve much on this advice.

Our knowledge of the associations between heat stress and nutrition comes partly from observations made in field studies, partly from the results of laboratory experiments and also, more recently, from valuable combinations of both these approaches.

\section{Assessment of evidence from nutritional field studies}

Nutritional field studies are exceedingly useful in establishing the important associations between dietary deficiencies and clinical signs of malnutrition, in 